\title{
Analisis Kebijakan Sistem Pengolahan Air Limbah Rumah Tangga Kota Depok
}

\author{
Policy Analysis of Household Wastewater Treatment System at Depok City
}

\section{Melania Hanny Aryantie ${ }^{1}$}

Pusat Penelitian dan Pengembangan Kualitas dan Laboratorium Lingkungan, Badan Litbang dan Inovasi, Kementerian Lingkungan Hidup dan Kehutanan, Tangerang Selatan, Indonesia

\section{Sri Unon Purwati}

Pusat Penelitian dan Pengembangan Kualitas dan Laboratorium Lingkungan, Badan Litbang dan Inovasi, Kementerian Lingkungan Hidup dan Kehutanan, Tangerang Selatan, Indonesia

Artikel Masuk : 9 Juli 2020

Artikel Diterima : 6 Juli 2021

Tersedia Online : 31 Agustus 2021

\begin{abstract}
Abstrak: Penelitian kebijakan pengelolaan air limbah domestik masih minim. Riset terdahulu yang ditemukan berbasis ilmu hukum. Penelitian ini dilakukan untuk melihat kebijakan dari sudut pandang hierarki peraturan pengelolaan air limbah domestik yang dilengkapi dengan analisis kebijakan berdasarkan pemahaman para pemangku kepentingan yang terlibat. Pengelolaan air limbah penting karena menyangkut kesehatan manusia dan ketersediaan air bersih. Persoalan di Kota Depok adalah air limbah domestik rumah tangga yang tidak diolah dan mencemari sungai. Kondisi ini disebabkan karena Instalasi Pengolahan Air Limbah (IPAL) komunal yang belum dapat menjangkau seluruh permukiman dan perumahan. Penelitian ini bertujuan untuk menganalisis kebijakan pengelolaan air limbah domestik untuk mengurangi pencemaran akibat kegiatan rumah tangga di Kota Depok. Penelitian dilaksanakan pada tahun 2018. Pengumpulan data dilakukan untuk data primer yang terdiri dari persepsi pemangku kebijakan limbah domestik di tingkat daerah hingga nasional. Data sekunder dikumpulkan dari hasil penelitian sebelumnya dan produk kebijakan Kota Depok. Penelitian kualitatif ditentukan dengan responden yang diperoleh dari hasil analisis isi dokumen dan analisis pemangku kepentingan. Data primer diperoleh melalui wawancara dan diskusi kelompok terpumpun. Temuan yang diperoleh adalah terjadinya pencemaran air limbah domestik dari permukiman yang berdiri sebelum tahun 2012 dan permukiman yang tidak terlayani IPAL komunal terpadu di Kota Depok. Dua kondisi tersebut dapat diatasi dengan membangun sistem pengolahan air limbah domestik berbiaya murah dan mudah dioperasikan. Rekomendasi yang diajukan adalah penerapan IPAL sanitasi taman berdasarkan riset yang sudah dilakukan sebelumnya. Implikasi kebijakan yaitu adopsi sistem IPAL tersebut di dalam peraturan pemerintah daerah Kota Depok.
\end{abstract}

Kata Kunci: kebijakan lingkungan; limbah domestik; nonkakus; permukiman; sanitasi taman

\footnotetext{
${ }^{1}$ Korespondensi Penulis: Pusat Penelitian dan Pengembangan Kualitas dan Laboratorium Lingkungan, Badan Litbang dan Inovasi Kementerian Lingkungan Hidup dan Kehutanan, Tangerang Selatan, Indonesia Email: melania.hanny@gmail.com
} 


\title{
173 Analisis Kebijakan Sistem Pengolahan Air Limbah Rumah Tangga Kota Depok
}

\begin{abstract}
Study on domestic wastewater management policies is still minimal. Previous research was based on law. This research was conducted to discuss according hierarchy of regulations, then policy analysis under the stakeholders' understanding. Wastewater management is important because it involves human health and the availability of clean water. The problem in Depok City is untreated domestic wastewater polluting rivers. This condition is caused by the communal Waste Water Treatment Plant (WWTP) that has not been able to reach all settlements and housing. The study aims to conduct a policy analysis of domestic wastewater management to reduce household pollution in Depok. The study was conducted in 2018. Primary data were consisting of perceptions of domestic waste policy makers at regional to national level. Secondary data were previous studies and policy products of Depok City. Qualitative research is determined by the results of content analysis and stakeholder analysis. Primary data obtained through interviews and focus group discussion. The finding is domestic wastewater pollution comes from settlements established before 2012 and settlements that are not served by integrated communal WWTP in Depok City. These conditions can be overcome by building inexpensive and easy to operate domestic wastewater treatment system. The research recommendation is the application of a constructed wetland. The policy implication is adoption of WWTP system in Depok City regulations.
\end{abstract}

Keywords: constructed wetland; domestic waste; environmental policy; greywater; settlement

\section{Pendahuluan}

Studi kebijakan terkait erat dengan keputusan pemerintah. Pemerintah mengatur dan mengembangkan kebijakan dalam rangka pengelolaan lingkungan hidup (Lazuardini et al., 2014) yang sifatnya wajib (Aryantie et al., 2018). Kebijakan lingkungan memiliki ruang lingkup luas seperti pengelolaan sampah perkotaan (Aryantie \& Hidayat, 2019; Surahma et al., 2016), ekonomi air (Berbel et al., 2017), perlindungan laut (Sarda et al., 2014), teknologi ramah lingkungan (Yazdani et al., 2018), dan pengelolaan limbah (Yudo \& Said, 2017). Kebijakan lingkungan menjadi salah satu faktor penentu tingkat kesehatan lingkungan wilayah. Melalui kebijakan lingkungan hidup yang tepat, pelaksana di lapangan memiliki arahan dan petunjuk dalam melakukan kegiatan yang ramah lingkungan.

Penelitian kebijakan tentang air limbah domestik, khususnya untuk permukiman masih jarang ditemukan. Padahal kawasan permukiman termasuk sumber pencemar acak limbah (Aryantie et al., 2017) hasil aktivitas rumah tangga atau domestik. Limbah domestik adalah salah satu penyumbang terbesar polusi sungai (Suswati et al., 2015). Bahkan baku mutu air limbah domestik dilegalkan tersendiri melalui Peraturan Menteri (Permen) LHK Nomor P.68/Menlhk/Setjen/Kum.1/8/2016 (KLHK, 2016), karena berpotensi mencemari lingkungan sehingga perlu diolah sebelum dibuang ke badan air (sungai, danau, atau laut).

Hasil penelitian kebijakan tentang air limbah domestik lingkup nasional telah dilakukan oleh Guntari (2015), Palilingan (2016), Yudo dan Said (2017), serta Palilingan et al. (2018). Akan tetapi, penelitian-penelitian tersebut termasuk dalam evaluasi peraturan berbasis ilmu hukum (Guntari, 2015; Palilingan, 2016; Palilingan et al., 2018). Guntari (2015) dan Palilingan (2016) membedah Undang-Undang (UU) Nomor 32 Tahun 2009 tentang Perlindungan dan Pengelolaan Lingkungan Hidup. Yudo dan Said (2017) menambahkan aspek teknologi lingkungan sebagai rekomendasi strategi pengelolaan air limbah domestik. Penelitian kebijakan lingkungan berbasis hukum yang telah dilakukan tidak menguraikan kerangka undang-undang dan regulasi hingga tingkat pelaksanaan. Dibandingkan dengan studi lainnya, penelitian ini dilakukan untuk melihat kebijakan dari sudut pandang hierarki peraturan pengelolaan air limbah domestik, dilengkapi dengan analisis kebijakan berdasarkan pemahaman para pemangku kepentingan yang terlibat. Pengembangan kebijakan ini mendukung perencanaan lingkungan kota, khususnya 
pengendalian pencemaran yang lebih banyak dihasilkan oleh wilayah perkotaan daripada penyangganya (Blanken et al., 2019). Melalui penelitian di Kota Depok, sumber permasalahan diurai dari peraturan yang masih berlaku dari tingkat undang-undang hingga peraturan daerah. Dari tahap ini, maka masalah dapat digali berdasarkan kondisi terkini di daerah.

Konsep yang digunakan adalah analisis kebijakan publik. Weimer \& Vining (2004) menyatakan tugas utama dalam menganalisis kebijakan adalah menjelaskan apa yang sedang terjadi dan apa yang akan terjadi melalui penerapan kebijakan alternatif. Melalui kebijakan, maka solusi suatu masalah didapatkan (Ekawati, 2016).

Isu lingkungan yang diteliti adalah pengelolaan air limbah domestik. Berdasarkan penelitian terdahulu bahwa limbah domestik mendominasi sumber polutan lingkungan (Suswati et al., 2015). Hasil analisis karakteristik limbah menyatakan bahwa salah satu sumber limbah domestik didominasi oleh aktivitas dapur (Han et al., 2015) atau nonkakus. Oleh karena itu diusulkan pengelolaan limbah domestik yang tepat bersifat komunal atau terpusat (Han et al., 2015; Abduli et al., 2008).

Analisis kebijakan dipilih karena bermanfaat bagi pengambil kebijakan untuk merancang kebijakan publik di wilayahnya (Aryantie et al., 2018). Melalui analisis kebijakan publik dapat diketahui perubahan yang diharapkan pemerintah melalui kebijakan yang dibuatnya (Dye, 1976). Perubahan yang disasar dalam penelitian ini adalah pencemaran sungai akibat air limbah rumah tangga dapat dikendalikan. Penelitian ini bertujuan untuk menganalisis kebijakan pengelolaan air limbah domestik untuk mengurangi pencemaran akibat kegiatan rumah tangga di Kota Depok. Hasil penelitian diharapkan dapat menjadi rekomendasi kebijakan bagi Pemerintah Kota Depok.

\section{Metode Penelitian}

Data dikumpulkan melalui beberapa tahap (Gambar 1). Pertama adalah data sekunder berupa dokumen peraturan dan kebijakan yang masih berlaku saat penelitian dilakukan. Produk hukum diuraikan untuk diketahui payung hukum utama yang menaungi kebijakan pengelolaan limbah domestik di Kota Depok. Dari tahap ini diperoleh informasi awal siapa saja para pemangku kepentingan yang berkaitan erat dengan topik riset.

Penelitian kualitatif ditentukan dengan responden yang diperoleh dari hasil analisis isi dokumen dan analisis pemangku kepentingan. Dokumen sebagai sumber informasi terkait kebijakan berupa karya tulis ilmiah, publikasi, dokumen pemerintah, dan media populer (Weimer \& Vining, 2004). Diawali dengan kerangka hukum Kota Depok, maka ditemukan dua instansi yang secara langsung menangani limbah domestik, yaitu Dinas Perumahan dan Permukiman (DPP) dan Dinas Lingkungan Hidup dan Kebersihan (DLHK). Keduanya menjadi target narasumber. Melalui analisis isi dapat diperoleh informasi awal mengenai cara pandang berbagai pihak dalam menyikapi masalah serta solusi yang diusulkan masingmasing (Legwegoh \& Fraser, 2015).

Tahap kedua adalah wawancara dengan berpedoman pada UU Nomor 12 Tahun 2011. UU ini dipilih karena hasil penelitian yang diharapkan adalah rekomendasi kebijakan yang bermuara ke pembuatan regulasi di daerah. Oleh karena itu, pedoman wawancara diarahkan memenuhi kaidah peraturan yang resmi.

Analisis pemangku kepentingan sebagai alat bantu penyusunan para pihak dan isu kebijakan (Hoppe \& Sanders, 2014). Analisis ini merupakan instrumen studi kebijakan untuk membangun struktur sosial para pihak yang saling tergantung satu sama lain (Hoppe \& Sanders, 2014). Hasil dari analisis pemangku kepentingan menjadi dasar penentuan para pihak yang diundang dalam diskusi kelompok terpumpun. Dari analisis ini, diperoleh pihakpihak dari beragam elemen masyarakat yang terlibat langsung maupun tidak langsung 
dalam pengelolaan air limbah domestik rumah tangga. Analisis pemangku kepentingan pada penelitian ini tidak mengelompokkan peran primer, sekunder, dan kunci seperti pada studi yang dilakukan oleh Putri dan Santoso (2020).

Metode terakhir adalah yuridis normatif sesuai dengan UU Nomor 12 Tahun 2011 tentang Pembentukan Peraturan Perundang-undangan (Pemerintah Republik Indonesia, 2011) melalui diskusi kelompok terpumpun (focus group discussion/FGD). Forum ini dilaksanakan sebagai sarana verifikasi perolehan data awal sekaligus menghimpun data dari berbagai pemangku kepentingan yang terdiri dari pemerintah, swasta, akademisi, dan masyarakat.

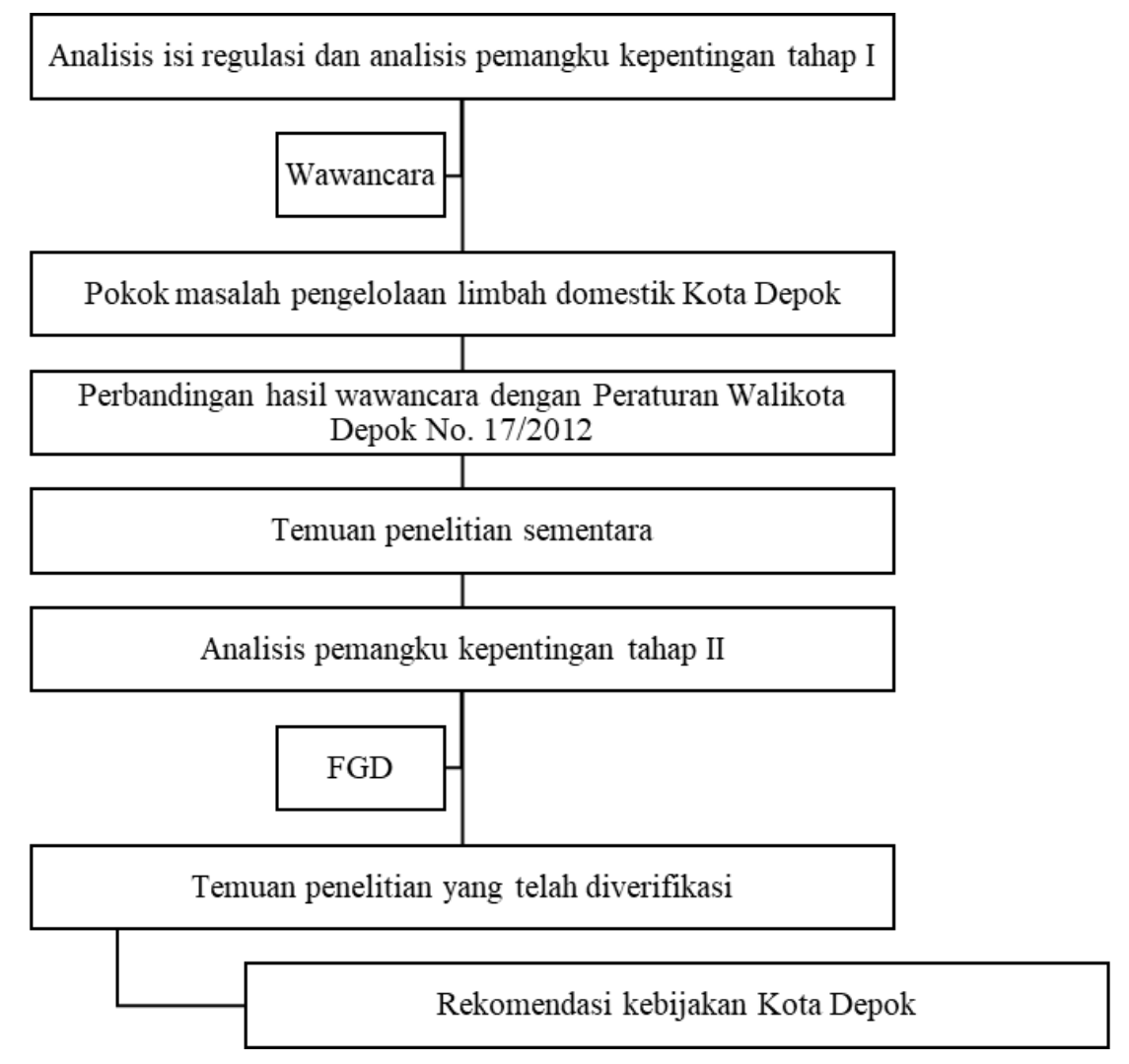

\section{Gambar 1. Alur Penelitian}

\section{Hasil dan Pembahasan}

Penelitian dimulai dengan menguraikan kerangka hukum yang berlaku saat penelitian dilaksanakan. Studi kerangka hukum berdasarkan analisis isi (content analysis) (Babbie, 2007; Legwegoh \& Fraser, 2015). Dari proses ini, maka diperoleh diagram pada Gambar 2. Dari diagram tersebut tergambar bahwa urusan pengelolaan air limbah domestik di Kota Depok merupakan gabungan dari bidang lingkungan hidup dan kehutanan serta bidang infrastruktur (perumahan dan permukiman). Oleh karena itu untuk menggali lebih dalam tentang kebijakan air limbah domestik, maka sasaran wawancara berdasarkan analisis pemangku kepentingan (stakeholder analysis) (Hoppe \& Sanders, 2014) adalah personil Pemerintah Kota Depok yang menangani kedua bidang tersebut.

Sesuai dengan tugas dan fungsi lembaga afiliasi, maka regulasi yang disasar adalah Peraturan Walikota (Perwali) Depok Nomor 17 Tahun 2012 tentang Pengolahan Air 
Limbah Domestik (Pemerintah Kota Depok, 2012) yang secara langsung merujuk pada peraturan lingkungan hidup (kotak diarsir). Sementara penelitian berjalan, Pemerintah Kota Depok sedang memproses pengesahan Peraturan Daerah (Perda) Kota Depok tentang Pengelolaan Air Limbah yang terbit di awal tahun 2019 (kotak diarsir: Perda Kota Depok Nomor 8 Tahun 2018). Outcome yang diharapkan dari penelitian ini adalah pemanfaatan hasil penelitian dalam penyusunan petunjuk teknis tentang pengolahan air limbah domestik, khususnya penerapan IPAL sanitasi taman untuk pengolahan limbah nonkakus dari kawasan permukiman (kotak bergaris putus-putus).

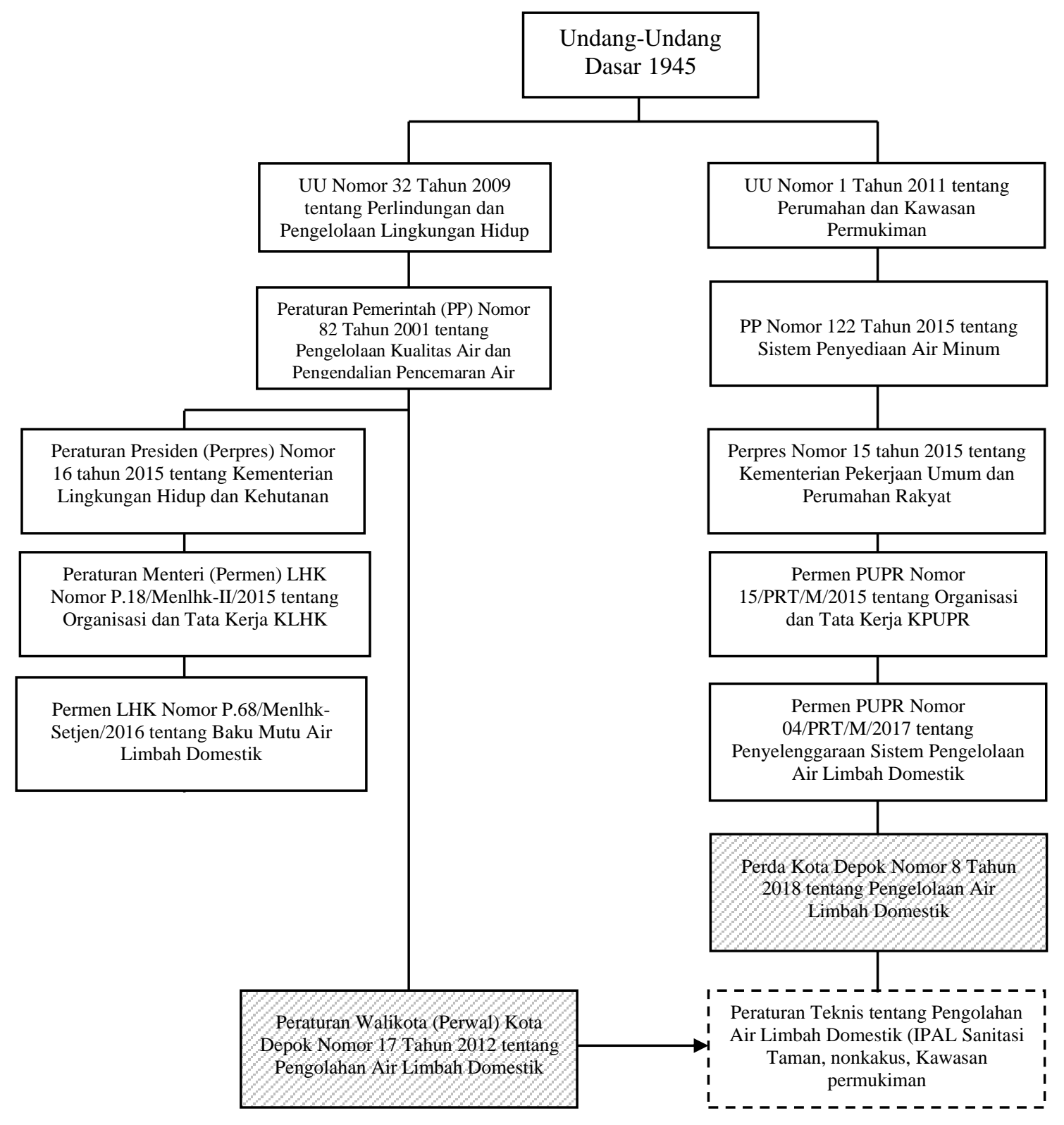

Sumber: Aryantie et al., 2018

Gambar 2. Kerangka Hukum Pengolahan Air Limbah Domestik di Kota Depok 


\section{Analisis Kebijakan Sistem Pengolahan Air Limbah Rumah Tangga Kota Depok}

Analisis kebijakan pengelolaan air limbah domestik mengacu pada peraturan yang masih berlaku saat penelitian di tahun 2018, yaitu Perwali Depok Nomor 17 Tahun 2012 tentang Pengolahan Air Limbah Domestik. Dasar kedua adalah Rancangan Peraturan Daerah (Ranperda) Kota Depok tentang Pengelolaan Air Limbah Domestik. Dari kedua produk tersebut, dilakukan analisis celah (gap analysis) dan diperoleh dua temuan awal, yaitu kewajiban pemasangan IPAL domestik tidak berlaku untuk permukiman dengan usia bangunan yang berlaku surut sebelum peraturan berlaku (sebelum tahun 2012) dan keberadaan kawasan permukiman yang memiliki tangki septik individual, tapi tidak memiliki pengolah limbah nonkakus (Aryantie et al., 2018).

Untuk menggali lebih dalam, maka dengan berpedoman pada UU Nomor 12 Tahun 2011, penelitian difokuskan pada tujuh komponen pengamatan, yang meliputi teknologi IPAL yang berlaku di Kota Depok, masalah sanitasi riil, celah hukum pembangunan IPAL permukiman, ruang lingkup regulasi yang berlaku, kelembagaan, peraturan sanitasi, dan jenis IPAL yang diterapkan di Kota Depok. Komponen-komponen tersebut menjadi pedoman wawancara narasumber DPP dan DLHK Kota Depok.

Tabel 1. Rangkuman Hasil Wawancara

\begin{tabular}{|c|c|c|c|}
\hline No & $\begin{array}{c}\text { Komponen yang } \\
\text { diamati }\end{array}$ & DLHK & DPP \\
\hline & Narasumber & $\begin{array}{l}\text { Kepala Bidang Pengendalian } \\
\text { Pencemaran dan Penataan } \\
\text { Lingkungan beserta staf }\end{array}$ & $\begin{array}{l}\text { Kepala Seksi Pengembangan } \\
\text { dan Pengelolaan Sistem Air } \\
\text { Limbah Domestik beserta staf }\end{array}$ \\
\hline 1 & $\begin{array}{l}\text { Teknologi IPAL yang } \\
\text { diatur dalam } \\
\text { peraturan yang } \\
\text { berlaku dan Ranperda }\end{array}$ & $\begin{array}{l}\text { Ranperda: } \\
\text { - Sistem pengelolaan air limbah } \\
\text { domestik setempat (on site); } \\
\text { - Sistem pengelolaan air limbah } \\
\text { domestik terpusat (off site); } \\
\text { - } \text { Instalasi Pengolahan Lumpur Tinja } \\
\text { (IPLT). }\end{array}$ & $\begin{array}{l}\text { Ranperda: } \\
\text { - Teknologi fabrikasi untuk } \\
\text { mengolah campuran black } \\
\text { water dan grey water; } \\
\text { - Konvensional untuk mengolah } \\
\text { black water saja. }\end{array}$ \\
\hline 2 & $\begin{array}{l}\text { Permasalahan sanitasi } \\
\text { di permukiman saat } \\
\text { ini }\end{array}$ & $\begin{array}{l}\text { Hasil pemantauan: parameter coliform } \\
\text { masih tinggi. }\end{array}$ & $\begin{array}{l}\text { Peraturan yang ada tidak } \\
\text { mengatur hulu-hilir secara } \\
\text { holistik; Ranperda dimaksudkan } \\
\text { untuk mengoordinasikan semua } \\
\text { tugas Organisasi Perangkat } \\
\text { Daerah (OPD) terkait. }\end{array}$ \\
\hline 3 & $\begin{array}{l}\text { Permasalahan hukum } \\
\text { dalam penerapan } \\
\text { IPAL saat ini }\end{array}$ & $\begin{array}{l}\text { Perwali Depok 17/2012 hanya } \\
\text { mengatur untuk bangunan yang } \\
\text { didirikan sejak tahun } 2012 \text { (tidak } \\
\text { berlaku surut). }\end{array}$ & Tidak tahu. \\
\hline 4 & $\begin{array}{l}\text { Ruang lingkup } \\
\text { pengaturan peraturan } \\
\text { yang berlaku }\end{array}$ & $\begin{array}{l}\text { Perwali Depok 17/2012 tidak } \\
\text { mengatur sanksi; sanksi mengacu UU } \\
\text { 32/2009 tentang PPLH dan Perda } \\
\text { Kota Depok 3/2013 tentang Pedoman } \\
\text { PPLH. }\end{array}$ & $\begin{array}{l}\text { Ranperda mengatur pengelolaan } \\
\text { black water dan grey water secara } \\
\text { terpadu. }\end{array}$ \\
\hline 5 & Kelembagaan & $\begin{array}{l}\text { Perwali Depok } 17 / 2012 \text { menunjuk } \\
\text { pengembang atau warga. }\end{array}$ & $\begin{array}{l}\text { Kelembagaan diatur Perwali } \\
\text { sebagai turunan Perda yang } \\
\text { sedang disempurnakan. }\end{array}$ \\
\hline 6 & $\begin{array}{l}\text { Peraturan terkait } \\
\text { sanitasi permukiman } \\
\text { yang diacu }\end{array}$ & $\begin{array}{l}\text { Permen LHK No. 68/2016 tentang } \\
\text { Baku Mutu Air Limbah Domestik; } \\
\text { implementasi yang sudah terlaksana } \\
\text { untuk rumah sakit dan IPLT. }\end{array}$ & $\begin{array}{l}\text { Permen PUPR No. } \\
\text { 04/PRT/M/2017 tentang } \\
\text { Penyelenggaraan Sistem } \\
\text { Pengelolaan Air Limbah } \\
\text { Domestik. }\end{array}$ \\
\hline 7 & Jenis IPAL di Depok & $\begin{array}{l}\text { IPAL yang dibangun DPP dengan } \\
\text { sistem biofilter. }\end{array}$ & $\begin{array}{l}\text { IPAL tangki septik; IPAL } \\
\text { wetland belum ada. }\end{array}$ \\
\hline
\end{tabular}


Hasil wawancara menggambarkan antara lain cara pandang dan solusi dari informan (Legwegoh \& Fraser, 2015). DLHK menilai bahwa dengan penerapan IPAL yang ada (sistem biofilter), masih tersisa masalah lingkungan berupa pencemaran coliform. Bangunan permukiman sebelum tahun 2012 tidak memiliki fasilitas IPAL sehingga air limbah langsung mengalir ke selokan. Penerapan sanksi berdasarkan Undang-undang Nomor 32 tahun 2009 terhadap pengembang atau warga sulit dikenakan untuk bangunan lama (Pemerintah Republik Indonesia, 2009). Selain itu, pengawasan pengendalian pencemaran air di permukiman belum diterapkan, tetapi sudah terlaksana untuk rumah sakit dan IPLT. Solusi dalam Ranperda Kota Depok meliputi sistem pengelolaan air limbah setempat, terpusat, dan IPLT.

Pihak DPP menilai bahwa peraturan yang ada belum mengatur pengelolaan air limbah secara menyeluruh. Sistem yang telah diterapkan adalah IPAL tangki septik. Ranperda tentang Pengelolaan Air Limbah Domestik dimaksudkan sebagai sarana koordinasi dinas-dinas terkait. Di dalamnya mengatur pengelolaan air limbah kakus (black water) dan nonkakus (grey water) dilakukan secara terpadu.

Dari hasil wawancara (Tabel 1) dengan Kepala Bidang Pengendalian Pencemaran dan Penataan Lingkungan DLHK Kota Depok dan Kepala Seksi Pengembangan dan Pengelolaan Sistem Air Limbah Domestik DPP Kota Depok, diperoleh informasi bahwa pokok permasalahan yang masih dihadapi adalah: (1) peraturan yang ada tidak mengatur hulu hingga hilir secara holistik; (2) peraturan yang ada hanya mengatur untuk bangunan perumahan yang didirikan sejak tahun 2012; dan (3) parameter coliform masih melebihi baku mutu limbah domestik dalam lampiran Peraturan Menteri LHK No. P.68/Menlhk/Setjen/Kum.1/8/2016 tentang Baku Mutu Air Limbah Domestik (KLHK, 2016). Sasaran Perwali Depok Nomor 17/2012 dibandingkan dengan permasalahan yang ditemui disajikan pada Tabel 2.

Dari Tabel 2, terlihat peluang untuk menerapkan teknologi IPAL yang telah ada disesuaikan dengan kondisi permukiman di Depok secara umum. IPAL difokuskan untuk mengolah air limbah nonkakus. Dari beberapa teknologi pengolahan limbah yang tersedia, IPAL sanitasi taman (sanita atau constructed wetland) diajukan sebagai pilihan. Alasan yang mendasari adalah IPAL sanita sudah terbukti dapat mengurangi kadar polutan air (Aryantie et al., 2019; Haryani et al., 2019), ramah lingkungan (Boufaroua et al., 2013), menggunakan prinsip fitoremediasi (Moenir, 2010; Suswati \& Wibisono, 2013; Mustafa, 2013), relatif murah (Aryantie et al., 2018; Mustafa, 2013), dan dapat dikelola oleh komunitas masyarakat (Asemota et al., 2011; Bright-Davies et al., 2015). Teknologi ini terbukti berhasil diterapkan di permukiman (Fu et al., 2018).

Penelitian dilanjutkan dengan analisis pemangku kepentingan untuk mengetahui para pihak yang terkait dengan pengelolaan limbah domestik. Para pemangku kepentingan tersebut berasal dari berbagai elemen dan latar belakang dengan perannya masing-masing seperti pada tertera di Tabel 3.

Identifikasi para pihak pada Tabel 3 meliputi empat elemen. Pertama adalah komunitas yang terdiri dari pengurus lingkungan (RT/RW) dan warga. Kedua adalah elemen pemerintah yang terdiri dari Direktorat Pengendalian Pencemaran Air Kementerian Lingkungan Hidup dan Kehutanan (PPA-KLHK), lembaga litbang pemerintah (Pusat Penelitian Permukiman - Kementerian Pekerjaan Umum dan Perumahan Rakyat (Puskim-KPUPR), dan Pusat Penelitian Limnologi - Lembaga Ilmu Pengetahuan Indonesia (P2L-LIPI)), Pemerintah Kota Depok (DLHK dan DPP), Kelompok Kerja Sanitasi Daerah Kota Depok (Pokja Sanitasi), Balai Besar Wilayah Sungai - KPUPR (BBWS Cilicis-KPUPR), serta Kelurahan. Ketiga adalah akademisi yang diwakili oleh Universitas Trisakti. Elemen keempat yaiu pebisnis terdiri dari pengembang perumahan/developer dan perusahaan air minum (PD PAM Jaya). Pada penelitian ini tidak dilakukan pemodelan pentahelix yang melibatkan elemen media massa (Putri dan Santoso, 2020) yang merupakan penerjemahan 
Peraturan Menteri Pariwisata Nomor 14 tahun 2016 mengenai peran bussiness, government, community, academic, and media (BGCAM). Model tersebut teruji untuk perencanaan pariwisata, namun belum banyak dikaji untuk perencanaan lingkungan.

Tabel 2. Celah Regulasi dan Peluang Rekomendasi Kebijakan

\begin{tabular}{|c|c|c|c|}
\hline $\begin{array}{c}\text { Sasaran Perwali Depok Nomor } \\
\text { 17/2012 Pasal } 2(3) \\
\end{array}$ & $\begin{array}{c}\text { Permasalahan } \\
\text { yang ditemui }\end{array}$ & Celah & Peluang \\
\hline $\begin{array}{l}\text { a. Penerapan pembuatan IPAL } \\
\text { komunal sistem terpusat } \\
\text { adalah untuk menekan tingkat } \\
\text { pencemaran air yang } \\
\text { sebagian besar dilakukan oleh } \\
\text { pencemaran air limbah } \\
\text { domestik yang akan dibuang } \\
\text { ke saluran kota/badan air } \\
\text { penerima. }\end{array}$ & $\begin{array}{l}\text { Pembuatan IPAL } \\
\text { komunal sistem } \\
\text { terpusat } \\
\text { membutuhkan } \\
\text { biaya besar (DPP } \\
\text { Depok, 26/03/18). }\end{array}$ & $\begin{array}{l}\text { Untuk permukiman } \\
\text { tipe lama, masih } \\
\text { terpasang sistem } \\
\text { pengelolaan air limbah } \\
\text { domestik setempat } \\
\text { untuk limbah kakus. } \\
\text { Sementara limbah } \\
\text { nonkakus langsung } \\
\text { dibuang melalui } \\
\text { saluran/ badan air. }\end{array}$ & $\begin{array}{l}\text { Pengolahan limbah } \\
\text { nonkakus yang } \\
\text { terpisah } \\
\text { membutuhkan biaya } \\
\text { lebih murah } \\
\text { dibandingkan } \\
\text { membongkar sistem } \\
\text { setempat lalu diganti } \\
\text { dengan sistem } \\
\text { terpusat. }\end{array}$ \\
\hline $\begin{array}{l}\text { b. Membatasi bahan } \\
\text { pencemaran yang ditenggang/ } \\
\text { ditoleransi masuk kedalam air } \\
\text { sebatas tidak akan } \\
\text { menyebabkan air menjadi } \\
\text { cemar. }\end{array}$ & $\begin{array}{l}\text { Parameter coliform } \\
\text { masih melebihi } \\
\text { baku mutu limbah } \\
\text { domestik (DLHK } \\
\text { Depok, 26/03/18). }\end{array}$ & $\begin{array}{l}\text { Baku mutu bakteri } \\
\text { coliform (Total } \\
\text { coliform) telah diatur } \\
\text { melalui PermenLHK } \\
\text { No. P.68/Menlhk- } \\
\text { Setjen/2016 tentang } \\
\text { Baku Mutu Air } \\
\text { Limbah Domestik. }\end{array}$ & $\begin{array}{l}\text { Perlakuan tambahan } \\
\text { untuk mengelola } \\
\text { parameter coliform } \\
\text { dengan berbagai } \\
\text { opsi teknologi yang } \\
\text { ada. }\end{array}$ \\
\hline $\begin{array}{l}\text { c. Pengolahan air limbah } \\
\text { domestik berlaku bagi: } \\
\text { 1. Asrama/rumah kost yang } \\
\text { berpenghuni } \geq 100 \text { orang, } \\
\text { semua kawasan perumahan } \\
\text { teratur, kawasan perkantoran, } \\
\text { kawasan perniagaan dan } \\
\text { apartemen; } \\
\text { 2. Rumah makan/restoran (luas } \\
\text { bangunan } 1000 \mathrm{~m}^{2} \text { ) atau } \\
\text { berdasarkan rekomendasi } \\
\text { Organisasi Perangkat Daerah } \\
\text { (OPD) terkait diperlukan } \\
\text { pengolahan. }\end{array}$ & $\begin{array}{l}\text { Peraturan yang ada } \\
\text { hanya mengatur } \\
\text { untuk bangunan } \\
\text { yang didirikan } \\
\text { sejak tahun } 2012 \text {. }\end{array}$ & $\begin{array}{l}\text { Target khusus riset ini } \\
\text { berupa kawasan } \\
\text { permukiman/ } \\
\text { perumahan teratur; } \\
\text { untuk bangunan yang } \\
\text { berdiri sebelum tahun } \\
2012 \text { tidak termasuk } \\
\text { sasaran dari peraturan } \\
\text { ini. }\end{array}$ & $\begin{array}{l}\text { Pengolahan air } \\
\text { limbah domestik } \\
\text { untuk permukiman } \\
\text { yang berdiri } \\
\text { sebelum tahun } 2012 \text {. }\end{array}$ \\
\hline
\end{tabular}

Para pihak dalam Tabel 3 memiliki kepentingan dan potensi masing-masing dalam pengelolaan air limbah domestik perkotaan. Mereka menjadi peserta diskusi kelompok terpumpun (FGD) untuk digali pendapatnya mengenai pengelolaan air limbah domestik yang dibutuhkan untuk memperluas pelayanan tersebut di Kota Depok. Hasil kajian awal dan masukan dari para peserta diskusi disandingkan dengan hasil analisis isi Perwali Depok Nomor 17 tahun 2012. Perbedaannya menjadi masukan untuk revisi peraturan tersebut atau sebagai bahan dalam penyusunan petunjuk teknis pembangunan IPAL sanita di kawasan perumahan. Hal ini adalah poin pembeda dari riset Guntari (2015) dan Palilingan (2016) yang melakukan evaluasi kebijakan air limbah domestik hanya di tingkat undangundang. 
Tabel 3. Hasil Analisis Pemangku Kepentingan

\begin{tabular}{|c|c|c|c|c|}
\hline Kategori dan sifat & $\begin{array}{c}\text { Pemangku } \\
\text { kepentingan }\end{array}$ & $\begin{array}{c}\text { Problem/ } \\
\text { kepentingan/ } \\
\text { ketertarikan }\end{array}$ & Potensi & $\begin{array}{c}\text { Keterlibatan } \\
\text { dalam } \\
\text { program } \\
\end{array}$ \\
\hline \multirow{3}{*}{$\begin{array}{l}\text { Primer: } \\
\text { memperoleh } \\
\text { manfaat langsung } \\
\text { IPAL }\end{array}$} & $\begin{array}{l}\text { 1. Pengurus } \\
\text { lingkungan } \\
(\mathrm{RT} / \mathrm{RW})\end{array}$ & $\begin{array}{l}\text { Kesehatan } \\
\text { lingkungan }\end{array}$ & $\begin{array}{l}\text { Mempunyai } \\
\text { pengaruh ke warga }\end{array}$ & $\begin{array}{l}\text { Pengelola } \\
\text { IPAL }\end{array}$ \\
\hline & 2. Warga & $\begin{array}{l}\text { Kesehatan } \\
\text { lingkungan }\end{array}$ & $\begin{array}{l}\text { Memiliki } \\
\text { tenaga/sumberdaya } \\
\text { manusia (SDM) }\end{array}$ & $\begin{array}{l}\text { Pengelola } \\
\text { IPAL }\end{array}$ \\
\hline & $\begin{array}{l}\text { 3. Perusahaan air } \\
\text { minum }\end{array}$ & $\begin{array}{l}\text { Kebutuhan sumber } \\
\text { air baku untuk air } \\
\text { minum }\end{array}$ & $\begin{array}{l}\text { Community social } \\
\text { responsibility (CSR) }\end{array}$ & $\begin{array}{l}\text { Pemanfaat } \\
\text { sumber air } \\
\text { baku }\end{array}$ \\
\hline \multirow{5}{*}{$\begin{array}{l}\text { Sekunder: sebagai } \\
\text { supporter } \\
\text { (teknis/teoritis) } \\
\text { atau mitra dalam } \\
\text { pembangunan } \\
\text { IPAL }\end{array}$} & $\begin{array}{l}\text { 1. Pemda Kota } \\
\text { Depok }\end{array}$ & $\begin{array}{l}\text { Pencapaian target } \\
\text { sanitasi kota }\end{array}$ & $\begin{array}{l}\text { Mempunyai } \\
\text { kewenangan tingkat } \\
\text { kota }\end{array}$ & $\begin{array}{l}\text { Pembangun } \\
\text { sarana IPAL }\end{array}$ \\
\hline & 2. Developer & $\begin{array}{l}\text { Kewajiban } \\
\text { developer }\end{array}$ & CSR & $\begin{array}{l}\text { Pembangun } \\
\text { sarana IPAL }\end{array}$ \\
\hline & 3. Kelurahan & $\begin{array}{l}\text { Pencapaian target } \\
\text { sanitasi kota }\end{array}$ & $\begin{array}{l}\text { Mempunyai } \\
\text { kewenangan tingkat } \\
\text { desa }\end{array}$ & $\begin{array}{l}\text { Pembina } \\
\text { masyarakat }\end{array}$ \\
\hline & $\begin{array}{l}\text { 4. Lembaga litbang } \\
\text { pemerintah }\end{array}$ & $\begin{array}{l}\text { Pengembangan } \\
\text { IPTEK }\end{array}$ & Menguasai IPTEK & Riset \\
\hline & 5. Akademisi & $\begin{array}{l}\text { Pengembangan } \\
\text { IPTEK }\end{array}$ & Menguasai IPTEK & $\begin{array}{l}\text { Pengabdian } \\
\text { masyarakat }\end{array}$ \\
\hline \multirow{3}{*}{$\begin{array}{l}\text { Tersier: tidak } \\
\text { terlibat langsung, } \\
\text { tetapi memiliki } \\
\text { pengaruh pada } \\
\text { penetapan } \\
\text { kebijakan air } \\
\text { limbah }\end{array}$} & 1.PPA-KLHK & $\begin{array}{l}\text { Penyusun } \\
\text { kebijakan air } \\
\text { limbah di pusat }\end{array}$ & $\begin{array}{l}\text { Mempunyai } \\
\text { kewenangan tingkat } \\
\text { nasional }\end{array}$ & Regulator \\
\hline & $\begin{array}{l}\text { 2. BBWS Cilicis- } \\
\text { KPUPR }\end{array}$ & $\begin{array}{l}\text { Pemegang izin } \\
\text { pembangunan } \\
\text { sepanjang } \\
\text { bantaran sungai }\end{array}$ & $\begin{array}{l}\text { Mempunyai } \\
\text { kewenangan tingkat } \\
\text { wilayah }\end{array}$ & Regulator \\
\hline & $\begin{array}{l}\text { 3. Pokja Sanitasi } \\
\text { Kota Depok }\end{array}$ & $\begin{array}{l}\text { Penyusun } \\
\text { kebijakan air } \\
\text { limbah di Kota } \\
\text { Depok }\end{array}$ & $\begin{array}{l}\text { Mempunyai } \\
\text { kewenangan tingkat } \\
\text { kota }\end{array}$ & Regulator \\
\hline
\end{tabular}

Sumber: Aryantie et al., 2018

Rekomendasi hasil FGD yang diajukan meliputi Bab IV yaitu tentang Persyaratan Teknis Pengolahan Air Limbah Domestik, Pasal 7, Ayat 1 dan 2, yaitu (a) populasi penghuni yang diolah limbahnya \pm 100 Kepala Keluarga/unit IPAL sanita; (b) jenis peruntukan bangunan adalah permukiman/perumahan; (c) saluran pembuangan air limbah domestik ditambahkan dengan "terpusat/komunal dan terpisah dengan saluran drainase/air hujan"; (d) sarana pengambilan sampel ditambahkan dengan "bak penampung air limbah dan saluran masuk (inlet) IPAL sanita”; dan (e) standar kelayakan teknis berupa rangkaian IPAL sanita yang dilengkapi dengan perangkap minyak, bak penampung, bak masuk, dan bak keluar. Selanjutnya pada Bab V yaitu Pelaksanaan dan Perawatan IPAL Terpadu, Pasal 8, Ayat 1 dan 2, yaitu (a) pihak yang melaksanakan dan merawat IPAL permukiman/ perumahan ditambahkan dengan "bimbingan teknis pemerintah daerah/peneliti/ akademisi"; dan (b) biaya perawatan IPAL ditambahkan dengan "pemerintah daerah, pemanfaat jasa air, dan dana desa/kelurahan".

Selain mengupas permasalahan dari Perwali Depok Nomor 17 tahun 2012, para peserta diskusi juga membahas pembentukan kelembagaan untuk kebijakan alternatif yang 
diajukan, yaitu penerapan IPAL sanita pada lokasi berdasarkan temuan penelitian ini. Hasil yang diperoleh menjadi masukan Pemerintah Kota Depok dalam mewujudkan pelayanan IPAL sanita.

Kelembagaan mencakup tiga pokok, yaitu kewenangan, lembaga, dan anggaran (Aryantie \& Hidayat, 2019; Pemerintah Republik Indonesia, 2011). Dari diskusi kelompok yang telah dilaksanakan dan dikaitkan dengan kelembagaan pengelolaan IPAL sanita, dapat disarikan peran dari masing-masing pihak dalam Tabel 4 dan Tabel 5. Temuan yang diperoleh adalah pengusulan dana desa sebagai sumber anggaran operasional IPAL dan perekrutan operator IPAL (Tabel 5). Hal ini menunjukkan bahwa informan FGD memiliki wawasan lingkungan dalam memanfaatkan dana pembangunan.

Tabel 4. Kewenangan dan Lembaga Pengelolaan IPAL Sanita

\begin{tabular}{|c|c|c|c|c|c|c|}
\hline \multirow[t]{2}{*}{ Kewenangan } & \multicolumn{6}{|c|}{ Lembaga } \\
\hline & Pemda & PT & RT/RW & Developer & Pengelola & LSM \\
\hline Menjamin keberlanjutan operasi IPAL & $\mathrm{V}$ & $\mathrm{V}$ & $\mathrm{V}$ & & & \\
\hline \multicolumn{7}{|l|}{ Sanita: } \\
\hline \multicolumn{7}{|l|}{ 1. mengidentifikasi karakter masyarakat } \\
\hline \multicolumn{7}{|l|}{ 2. membentuk kelembagaan pengelola } \\
\hline \multicolumn{7}{|l|}{ 3. merekrut tenaga operator } \\
\hline $\begin{array}{l}\text { Pemerataan sanitasi lingkungan di kedua } \\
\text { tipe permukiman: }\end{array}$ & $\mathrm{V}$ & & & $\mathrm{V}$ & & \\
\hline \multicolumn{7}{|l|}{ Membangun IPAL Sanita di permukiman } \\
\hline Menjamin keberlanjutan operasi IPAL & $\mathrm{V}$ & & $\mathrm{V}$ & & $\mathrm{V}$ & \\
\hline \multicolumn{7}{|l|}{ Sanita: } \\
\hline \multicolumn{7}{|l|}{ 1. merawat IPAL Sanita } \\
\hline \multicolumn{7}{|l|}{ 2. menggaji operator } \\
\hline Menjamin keberlanjutan operasi IPAL & $\mathrm{V}$ & V & & & & V \\
\hline \multicolumn{7}{|l|}{ Sanita: } \\
\hline \multirow{2}{*}{\multicolumn{7}{|c|}{$\begin{array}{l}\text { 1. melakukan sosialisasi operasional, } \\
\text { perawatan, dan pemanfaatan air olahan }\end{array}$}} \\
\hline & & & & & & \\
\hline \multicolumn{7}{|l|}{ IPAL Sanita } \\
\hline \multicolumn{7}{|l|}{ 2. melakukan penyuluhan tentang } \\
\hline \multicolumn{7}{|l|}{ pemanenan tanaman air dan } \\
\hline \multirow{2}{*}{\multicolumn{7}{|c|}{$\begin{array}{l}\text { pengomposan } \\
\text { Sumber: Aryantie et al., } 2018\end{array}$}} \\
\hline & & & & & & \\
\hline $\begin{array}{l}\text { Keterangan: Pemerintah daerah (Pemd } \\
(\mathrm{RT} / \mathrm{RW}) \text {; Lembaga Swadaya Masyarakat }\end{array}$ & $\begin{array}{l}\text { Perguruar } \\
\mathrm{M})\end{array}$ & $\mathrm{Ti}$ & & Rukun $\mathrm{Te}$ & ga/Rukur & Warga \\
\hline
\end{tabular}

Melalui penelitian yang telah dilakukan, maka temuan kondisi pengelolaan limbah domestik di kota Depok dapat digambarkan sebagai berikut: (1) telah ada regulasi tentang pengolahan limbah domestik; (2) IPAL domestik tidak wajib bagi permukiman sebelum tahun 2012; (3) limbah nonkakus di sebagian permukiman tidak terolah; (4) pelayanan IPAL komunal terpadu telah ada, tetapi baru dapat menjangkau sebagian lokasi permukiman, dan (5) bakteri coliform masih menjadi masalah pencemaran. Kondisi yang nyata tersebut perlu solusi. Hal ini mendukung teori Weimer \& Vining (2004) bahwa hasil analisis kebijakan menjelaskan yang sedang terjadi (nyata/aktual) dan pernyataan Ekawati (2016) bahwa kebijakan dapat menjadi solusi suatu masalah.

Kebijakan harus menjawab permasalahan yang tepat supaya efektif (Ekawati, 2016). Kebijakan alternatif yang direkomendasikan untuk mengisi kekosongan pelayanan pengolahan air limbah domestik di kawasan permukiman Kota Depok adalah dengan menerapkan IPAL sanita (constructed wetland) (Fu et al., 2018) yang relatif murah (Aryantie et al., 2018; Mustafa, 2013) daripada teknologi biofilter (Yudo dan Said, 2017). IPAL sanita dapat menjangkau permukiman perkotaan dengan keterbatasan lahan dan 
dapat dikelola secara mandiri oleh penduduk (Asemota et al., 2011; Bright-Davies et al., 2015). Skema kelembagaan yang meliputi lembaga, wewenang, dan pendanaan yang telah disarikan dalam penelitian sebagai rekomendasi pengelolaan IPAL sanita di tingkat pelaksana. Dana desa menjadi salah satu usulan sumber anggaran operasional IPAL. Melalui penelitian yang dilakukan, temuan studi disusun menjadi komponen kebijakan Pemerintah Kota Depok sehingga dapat dimanfaatkan untuk mengelola dan mengontrol sumber acak air limbah domestik di wilayahnya, khususnya untuk kawasan permukiman

Tabel 5. Kewenangan dan Sumber Anggaran Pengelolaan IPAL Sanita

\begin{tabular}{|c|c|c|c|c|c|c|}
\hline \multirow[b]{2}{*}{ Kewenangan } & \multicolumn{6}{|c|}{ Anggaran } \\
\hline & APBD & PT & $\begin{array}{l}\text { Dana desa/ } \\
\text { kelurahan }\end{array}$ & Swasta & PAM & $\begin{array}{l}\text { Iuran } \\
\text { warga }\end{array}$ \\
\hline $\begin{array}{l}\text { Menjamin keberlanjutan operasi IPAL } \\
\text { Sanita: } \\
\text { 1. mengidentifikasi karakter masyarakat } \\
\text { 2. membentuk kelembagaan pengelola } \\
\text { 3. merekrut tenaga operator }\end{array}$ & V & $\mathrm{V}$ & V & & & \\
\hline $\begin{array}{l}\text { Pemerataan sanitasi lingkungan di kedua } \\
\text { tipe permukiman: } \\
\text { Membangun IPAL Sanita di permukiman }\end{array}$ & V & & & V & & \\
\hline $\begin{array}{l}\text { Menjamin keberlanjutan operasi IPAL } \\
\text { Sanita: } \\
\text { 1. merawat IPAL Sanita } \\
\text { 2. menggaji operator }\end{array}$ & V & & V & & V & V \\
\hline $\begin{array}{l}\text { Menjamin keberlanjutan operasi IPAL } \\
\text { Sanita: } \\
\text { 1. melakukan sosialisasi operasional, } \\
\text { perawatan, dan pemanfaatan air olahan } \\
\text { IPAL Sanita } \\
\text { 2. melakukan penyuluhan tentang } \\
\text { pemanenan tanaman air dan } \\
\text { pengomposan }\end{array}$ & V & $\mathrm{V}$ & & & & \\
\hline
\end{tabular}

Sumber: Aryantie et al., 2018

Keterangan singkatan: Anggaran Pendapatan dan Belanja Daerah (APBD); Perguruan Tinggi (PT); Perusahaan Air Minum (PAM)

\section{Kesimpulan}

Hasil penelitian menunjukkan bahwa peraturan daerah Kota Depok belum mengatur pengelolaan air limbah domestik secara menyeluruh. Kawasan yang limbah domestiknya belum terkelola adalah kawasan permukiman yang dibangun sebelum tahun 2012 dan permukiman yang tidak terlayani IPAL komunal terpadu. Dengan dasar pertimbangan kesediaan lahan, ekonomi, dan teknis penduduk, rekomendasi kebijakan alternatif yang diajukan adalah menerapkan teknologi IPAL sanitasi taman pada kedua kondisi kawasan tersebut.

IPAL sanita hanya salah satu teknologi pengolahan air limbah yang berkembang saat ini dan terbukti secara ilmiah mengurangi polutan air. Pengajuan IPAL tersebut didukung penelitian tersendiri pada tahun 2015-2017. Riset kebijakan memperkuatnya dengan menjawab permasalahan lapangan, memberi masukan langsung terhadap regulasi berlaku, dan menyusun skema kelembagaan pengelola IPAL alternatif untuk penerapannya. 


\section{Analisis Kebijakan Sistem Pengolahan Air Limbah Rumah Tangga Kota Depok}

Penelitian ini memiliki kelebihan yaitu dilaksanakan berdasarkan kerangka hukum yang berlaku dan data dihimpun dari pemangku kepentingan dengan beragam elemen. Oleh karena itu, hasil penelitian ini dapat dikaji untuk menata ulang regulasi air limbah domestik di kawasan permukiman perkotaan yang berkarakter mirip dengan Kota Depok.

\section{Ucapan Terima Kasih}

Penulis mengucapkan terima kasih kepada Pusat Penelitian dan Pengembangan Kualitas dan Laboratorium Lingkungan (P3KLL) yang telah memberi dukungan anggaran penelitian ini. Penulis juga mengucapkan terima kasih kepada Pemerintah Kota Depok atas diadopsinya hasil penelitian ini di dalam Peraturan Daerah Kota Depok Nomor 8 tahun 2018 tentang Pengelolaan Air Limbah Domestik.

\section{Daftar Pustaka}

Abduli, M. A., Samieifard, R., \& Jalili Ghazi Zade, M. (2008). Rural solid waste management. International Journal of Environmental Research, 2(4), 425-430.

Aryantie, M. H., \& Hidayat, M. Y. (2019). Regulatory evaluation of waste management institutions in Yogyakarta, Sleman, and Bantul Metropolitan Areas. IOP Conference Series: Earth and Environmental Science 407. doi:10.1088/1755-1315/407/1/012015.

Aryantie, M. H., Purwati, S. U., Hadisoebroto, R., Pitalokasari, O. D., \& Nugroho, U. (2018). Pembangunan demplot biosanita: Peran sanitasi taman dalam upaya pengendalian pencemaran air untuk mendukung kebijakan daerah.

Aryantie, M. H., Purwati, S. U., Hadisoebroto, R., Pitalokasari, O. D., \& Nugroho, U. (2019). Kebijakan pengolahan limbah domestik non kakus untuk mendukung pencapaian target 100 persen akses sanitasi (Policy Brief 1-6). Kementerian Lingkungan Hidup dan Kehutanan.

Aryantie, M. H., Purwati, S. U., \& Pitalokasari, O. D. (2017). Kualitas limbah domestik dan partisipasi masyarakat yang peduli lingkungan di perumahan permata depok klaster mirah 1 dan 2. In B. Setiawan, S. Santoso, H. Suseno, Aisyah, D. H. Nugroho, M. H. Thayib, \& H. S. Hasibuan (Eds.), Pengelolaan limbah yang inovatif, handal, dan berkelanjutan sebagai wujud kepedulian terhadap lingkungan (pp. 121-128). Jakarta: Batan.

Asemota, L., Alkhaddar, R., Sertyesilisik, B., \& Tunstall, A. (2011). Wastewater management in lagos state: moving toward a more sustainable approach. Environmental Quality Management, 20(4), 63-72. doi:10.1002/tqem.20300.

Babbie, E. (2007). The practise of social research (11th ed.). Belmont, CA: Thomson Wadsworth.

Berbel, J., Gutiérrez-Martín, C., \& Martin-Ortega, J. (2017). Water economics and policy. Water, 9(10), 1-5. doi:10.3390/w9100801.

Blanken, M., Verweij, C., \& Mulder, K. (2019). Why novel sanitary systems are hardly introduced? Journal of Sustainable Development of Energy, Water and Environment Systems, 71), 13-27. doi:10.13044/j.sdewes.d6.0214.

Boufaroua, M., Albalawneh, A., \& Oweis, T. (2013). Assessing the efficiency of grey-water reuse at household level and its suitability for sustainable rural and human development. British Journal of Applied Science \& Technology, 3(4), 962-972.

Bright-Davies, L., Lüthi, C., \& Jachnow, A. (2015). DEWATS for urban Nepal: A comparative assessment for community wastewater management. Waterlines, 34(2), 119-138. doi:10.3362/1756-3488.2015.012.

Dye, T. R. (1976). Policy analysis. Alabama: The University of Alabama Press.

Ekawati, S. (2016). Mengkritisi kebijakan penanganan kantong plastik di indonesia (Policy Brief 1-4). Kementerian Lingkungan Hidup dan Kehutanan.

Fu, X., Wu, X., Zhou, S., Chen, Y., Chen, M., \& Chen, R. (2018). A constructed wetland system for rural household sewage treatment in subtropical regions. Water, 196), 1-12. doi:10.3390/w10060716. 
Guntari, U. (2015). Pelaksanaan kebijaksanaan perlindungan dan pengelolaan limbah domestik (studi pencemaran sungai cimanuk di Kabupaten Garut). Jurnal Intan Pro Justice, 2(1), 1-22.

Han, Z., Liu, D., Lei, Y., Wu, J., \& Li, S. (2015). Characteristics and management of domestic waste in the rural area of Southwest China. Waste Management \& Research: The Journal for a Sustainable Circular Economy, 33(1), 39-47. doi:10.1177/0734242X14558668.

Haryani, M. F., Hadisoebroto, R., \& Aryantie, M. H. (2019). Pengolahan air limbah non kakus permukiman menggunakan lahan basah buatan sebagai pilihan layanan dasar lingkungan perkotaan. In I. Krisantia, Ratnaningsih, E. Fatimah, \& D. Hendrawan (Eds.), Seminar Pembangunan Wilayah dan Kota Berkelanjutan (pp. 159-165). FALTL Universitas Trisakti. doi: 10.25105/pwkb.v1i1.5272.

Hoppe, T., \& Sanders, M. P. T. (2014). Agricultural green gas demonstration projects in the Netherlands. A stakeholder analysis. Environmental Engineering and Management Journal, 13(12), 3083-3096.

Kementerian Lingkungan Hidup dan Kehutanan (KLHK). (2016). Peraturan Menteri LHK Nomor P.68/Menlhk/Setjen/Kum.1/8/2016 tentang baku mutu air limbah domestik. Retrieved from: http://neo.kemenperin.go.id/files/hukum/19 Permen LHK th 2016 No. P.63 Baku Mutu Air Limbah Domestik.pdf.

Lazuardini, P. M., Mardiyono, M., \& Said, A. (2014). Analisis peranan pemerintah terhadap perlindungan dan pengelolaan lingkungan hidup (suatu studi di lingkungan kawasan industri gresik/KIG. Jurnal Administrasi Publik, 2(6). Retrieved from: http://administrasipublik.studentjournal.ub.ac.id/index.php/jap/article/view/499.

Legwegoh, A. F., \& Fraser, E. D. G. (2015). Food crisis or chronic poverty: Metanarratives of food insecurity in Sub-Saharan Africa. Journal of Hunger and Environmental Nutrition, 19(3), 313-342. doi:10.1080/19320248.2014.962777.

Moenir, M. (2010). Kajian fitoremidiasi sebagai alternatif pemulihan tanah tercemar logam berat. Jurnal Riset Teknologi Pencegahan Pencemaran Industri, 1(2), 104-176.

Surahma, A, M., Husodo, A. H., \& Muhadjir, N. (2016). Analisis situasi permasalahan sampah kota Yogyakarta dan kebijakan penanggulangannya. Kemas: Jurnal Kesehatan Masyarakat, 11(2), 96-106. doi:10.15294/kemas.v11i2.3989.

Mustafa, A. (2013). Constructed wetland for wastewater treatment and reuse: a case study of developing country. International Journal of Environmental Science and Development, 4(1), $20-24$. doi:10.7763/IJESD.2013.V4.296.

Palilingan, T. N. (2016). Pembentukan peraturan daerah dalam rangka pengelolaan limbah domestik. Lex et Societatis, 4(9), 44-52.

Palilingan, T. N., Setiabudhi, D. O., \& Palilingan, T. K. R. (2018). Environmental policy, public health and human rights: Assessing the regional regulation on waste. Hasanuddin Law Review, 4(3), 339-347. doi:10.20956/halrev.v4i3.1413.

Pemerintah Kota Depok. (2012). Peraturan Walikota Depok Nomor 17 tahun 2012 tentang Pengolahan Air limbah domestik. Retrieved from: https://www.depok.go.id/Perwal/2012/Perwal No.17 tahun 2012.pdf.

Pemerintah Republik Indonesia. (2009). Undang-undang nomor 32 tahun 2009 tentang perlindungan dan pengelolaan lingkungan hidup. Jakarta.

Pemerintah Republik Indonesia. (2011). Undang-Undang Nomor 12 tahun 2011 tentang pembentukan peraturan perundang-undangan. Jakarta.

Putri, P. A. V. A., \& Santoso, E. B. (2020). Analisis pemangku kepentingan dalam pengembangan kawasan cagar budaya sebagai destinasi wisata Kota Pontianak. Jurnal Wilayah dan Lingkungan, 8(3), 202-213. doi:10.14710/jwl.8.3.202-213.

Sarda, R., O’Higgins, T., Cormier, R., Diedrich, A., \& Tintoré, J. (2014). A proposed ecosystem-based management system for marine waters: linking the theory of environmental policy to the practice of environmental management, Ecology and Society, 19(4), 51. doi:10.5751/ES-07055-190451.

Suswati, S., Purna, A, C, S., Wibisono, G., Masrevaniah, A., \& Arfiati, D. (2015). Performance of natural mixed in comparation to plug flow sub surface constructed wetlands using vetiver grass (zizanioides) in sun exposure area (case study at Malang, Indonesia). Australian Journal of Basic and Applied Sciences, 9(27), 317-326.

Suswati, S., Purna, A, C, S., \& Wibisono, G. (2013). Pengolahan limbah domestik dengan teknologi taman tanaman air (constructed wetlands). Indonesian Green Technology Journal, 2(2), 70-77. 


\section{Analisis Kebijakan Sistem Pengolahan Air Limbah Rumah Tangga Kota Depok}

Weimer, D. I., \& Vining, A. R. (2004). Policy analysis: Concepts and practise (4th ed.). Pearson Prentice Hall.

Yazdani, M., Chatterjee, P., Zavadskas, E. K., \& Streimikiene, D. (2018). A novel integrated decision-making approach for the evaluation and selection of renewable energy technologies. Clean Technologies and Environmental Policy, 20(2), 403-420. doi:10.1007/s10098-018-1488-4.

Yudo, S., \& Said, N. I. (2017). Kebijakan dan strategi pengelolaan air limbah domestik di Indonesia. Jurnal Rekayasa Lingkungan, 10(2), 58-75. 